\title{
The action of GLP-1 and exendins upon glucose transport in normal human adipocytes, and on kinase activity as compared to morbidly obese patients
}

\author{
VERÓNICA SANCHO ${ }^{1}$, BERNARDO NUCHE ${ }^{1}$, LUIS ARNÉS ${ }^{1}$, JESÚS CANCELAS ${ }^{1}$, \\ NIEVES GONZÁLEZ ${ }^{1}$, MARIANO DÍAZ-MIGUEL ${ }^{2}$, ANTONIO MARTÍN-DUCE ${ }^{3}$, \\ ISABEL VALVERDE $^{1}$ and MARÍA L. VILLANUEVA-PEÑACARRILLO ${ }^{1}$
}

\author{
Departments of ${ }^{1}$ Metabolism, Nutrition and Hormones, ${ }^{2}$ General Surgery, Fundación Jiménez Díaz, \\ Avda. Reyes Católicos 2, 28040 Madrid; ${ }^{3}$ Department of Surgery, Hospital Príncipe de Asturias, \\ Universidad de Alcalá de Henares, Ctra. Meco (M-121) s/n, Alcalá de Henares, 28805 Madrid, Spain
}

Received January 30, 2007; Accepted March 12, 2007

\begin{abstract}
A role of GLP-1 (glucagon-like peptide-1) in the recovery of the metabolic conditions of morbidly obese patients after bariatric surgery has been proposed. Exendin 4 (Ex-4) and exendin 9 (Ex-9) both have GLP-1-like effects upon glucose metabolism in human myocytes. We investigated in normal human adipocytes the effect of GLP-1, Ex-4 and Ex-9, compared with insulin upon the activity of PI3K, PKB, MAPKs and p70s6 kinases, and the participation of these enzymes in their action upon 2-deoxy-D-glucose transport by using potential inhibitors. The study was extended to morbidly obese patients. In normal subjects, GLP-1, Ex-4 and insulin, but not Ex-9, increased glucose uptake. In addition, GLP-1 and Ex-4 stimulated PI3K and MAPKs, similar to insulin, but not PKB. Ex-9 only enhanced PI3K, while none affected p70s6k. Inhibition of both PI3K and MAPKs blocked the stimulatory action of GLP-1, Ex-4 and insulin upon glucose transport. In obese patients, basal PI3K, PKB and MAPK activity was, as a rule, lower than that in normal subjects, while cells maintained their normal incremental response to GLP-1, Ex-4 or insulin; Ex-9 induced a clear stimulation of p42 MAPK. In summary, in normal human adipocytes, GLP-1 and Ex-4 have a protein kinase-dependent increasing effect upon glucose transport, which is impaired in obese patients. The participation of GLP-1 in the normalization of the metabolic conditions of the obese may occur through its effects on lipid metabolism or through effects upon glucose transport and/or metabolism in the liver and muscle, which in human obesity remain to be investigated.
\end{abstract}

Correspondence to: Dr Maria L. Villanueva-Peñacarrillo, Metabolismo, Nutrición y Hormonas, Fundación Jiménez Díaz, Avda. Reyes Católicos 2, 28040 Madrid, Spain

E-mail: mlvillanueva@fjd.es

Key words: GLP-1, exendins, glucose transport, protein kinases, adipocytes, normal subjects, morbidly obese patients

\section{Introduction}

GLP-1 (glucagon-like peptide-1) has glucose-dependent insulinotropic action and insulin-independent antidiabetic character (1), apart from proven insulinomimetic properties per se (2). A stimulatory effect upon both the expression of glucotransporter genes (3) and the transport and metabolism of glucose in extrapancreatic tissues (2-5) has been reported. The effect of GLP-1 in the liver $(6)$ and muscle $(7,8)$ is exerted through specific receptors (9-11), structurally or functionally distinct $(6,7,12)$ from that in the pancreas $(13)$. But in normal rat and human adipocytes, GLP-1 has, in addition, a dual effect upon the lipid metabolism $(5,14-16)$, being both lipogenic and lipolytic depending upon the dose. Thus, GLP-1 could be acting through two different types of receptors in fat tissue where, in fact, this peptide not only stimulates inositolphosphoglycan (IPG) generation (17) but, distinct to its action in the liver and muscle $(8,17-19)$, also increases cellular cAMP content (14). Concerning the effects of GLP-1 in these three extrapancreatic tissues, several protein kinases have been implicated $(5,20,21)$.

GLP-1 inhibits gastric emptying and controls food intake by enhancing satiety (1). Moreover, a lower GLP-1 secretion, both basal and oral glucose- or meal-stimulated, has been reported in morbidly obese patients (22-24), which is reversed after bariatric surgery (24).

Exendin(1-39)amide (Ex-4), a peptide of non-mammalian nature, is $53 \%$ structurally homologous with GLP-1. It is also insulinotropic (25), and has GLP-1-like effects upon parameters related to the glucose metabolism in rat liver and skeletal muscle (26). Its truncated form exendin(9-39)amide (Ex-9), has been proven to be an antagonist of the GLP-1 receptor in various cell systems (27) and also of its effects in rat pancreas (28), liver cells and muscle tissue (26). Similar to Ex-4, it is agonist of its action in human muscle $(8,29)$, and also of its receptor in adipocyte (30) and myocyte (12) cell lines.

In a recent study, we reported the effect of GLP-1 and exendins upon glucose transport and lipid metabolism in adipocytes from a type 2 diabetic rat model compared to 
normal rat, which has further elucidated the mechanism of the beneficial action of these peptides in the diabetic state (5). Also recently, the reduced lipogenic effect and enhanced lipolytic action of GLP-1 has been observed in the fat tissue of morbidly obese patients, an effect adequate for its therapeutic use in obesity (31).

In this study we have explored the effect of GLP-1 and exendins, compared to that of insulin, on glucose transport in normal human adipocytes, the possible kinases involved and the differences in their action in cells from morbidly obese subjects.

\section{Materials and methods}

Reagents. The following reagents were used: human GLP-1 (7-36)amide (GLP-1, Bachem AG, Bubendorf, Switzerland); porcine insulin (Novo Biolabs, Bagsvaerd, Denmark); exendin(1-39)amide (Ex-4) and exendin(9-39)amide (Ex-9) (gifts from Dr John Eng, VAMC, NY, USA); PD98059 (PD) (Calbiochem $^{\circledR}$, La Jolla, CA, USA); collagenase P (Roche Diagnostics GmbH, Mannheim, Germany); ethylene glycol bis(ß-aminoethyl ether)-N,N,N'N'-tetraacetic acid (EGTA), ethylenedinitrilo-tetraacetic acid (EDTA), bovine serum albumin (BSA), wortmannin (W), cytochalasin B, phenylmethylsulfonyl fluoride (PMSF), phosphatidylinositol and phosphatidyl-serine (Sigma Chemical Co., St. Louis, MO, USA); aprotinin (Trasylol ${ }^{\circledR}$, Bayer Leverkusen, Germany); 2-deoxy-D-[1 ,2- ${ }^{3} \mathrm{H}(\mathrm{N})$ ]glucose (2-DOG, Moravek Biochemicals, Brea, CA, USA); Ultima Gold scintillation liquid (Packard, Gröninger, The Netherlands); $\left[\gamma^{32} \mathrm{P}\right]$ ATP (30 $\mathrm{Ci} / \mathrm{nmol})$, horseradish peroxidase-conjugated donkey anti-rabbit immunoglobulin, Rainbow markers, ECL-Western blotting kit, Hyperfilm ECL (Amersham Biosciences, Buckinghamshire, UK); rabbit anti-total and antiphosphorylated form of p44/42MAP kinases, p70s6k and PKB (Cell Signalling Technology, New England Biolabs, Beverly, MA, USA); and rabbit anti-PI3-kinase p85 (Upstate Biotechnology, Lake Placid, NY, USA). All other commonly used chemicals were from Sigma or Merck (Merck Pharma Quimica, S.A., Barcelona, Spain).

Biological material. Residual samples of subcutaneous abdominal fat tissue were collected after informed consent was obtained from 31 normal subjects (14 female/17 male; $58 \pm 3$ years old; fasting plasma D-glucose, $5.00 \pm 0.13 \mathrm{mM}$ ) during an inguinal hernia or plastic surgery, and from 9 morbidly obese patients ( 7 female/2 male; $43 \pm 3$ years old; BMI, $49.6 \pm 2.7 \mathrm{~kg} / \mathrm{m}^{2}$; fasting plasma D-glucose, $111.2 \pm 6.3 \mathrm{mM}$; cholesterol, $187.3 \pm 13.0 \mathrm{mg} / \mathrm{dl}$; triglycerides, $128.1 \pm 11.7 \mathrm{mg} /$ $\mathrm{ml}$; HDL, $53.1 \pm 4.9 \mathrm{mg} / \mathrm{ml}$; and LDL, $106.8 \pm 27.5 \mathrm{mg} / \mathrm{ml}$ ) undergoing bariatric surgery. The patients were randomly selected. In all cases, comparisons between normal subjects and obese patients were restricted to results obtained under similar experimental conditions.

The study was approved by the Ethics Committee of the Fundación Jiménez Díaz, Madrid, in accordance with the guidelines proposed in The Declaration of Helsinki.

Cells. Adipocytes were isolated at $37^{\circ} \mathrm{C}$ by enzymatic digestion with collagenase $\mathrm{P}$ from subcutaneous fat tissue
(32). Then, cells were re-suspended in KRB supplemented with $10.9 \mathrm{mM}$ HEPES, $500 \mathrm{KIU} / \mathrm{ml}$ Trasylol, BSA and without or with D-glucose, $\mathrm{pH} 7.4$, at a density of $10^{6}$ cells $/ \mathrm{ml}$.

Kinase activity. Cells $\left(10^{6}\right)$ were first incubated for $15 \mathrm{~min}$ in $1 \mathrm{ml} \mathrm{KRB}$ containing $30 \mathrm{mM}$ HEPES, $500 \mathrm{KIU} / \mathrm{ml}$ Trasylol, $1 \% \mathrm{BSA}$, and $3.3 \mathrm{mM}$ D-glucose, $\mathrm{pH} 7.4$, followed by a 3-min incubation in the absence or additional presence of GLP-1, Ex-4, Ex-9 or insulin. For the measurement of PI3K activity and that of phosphorylated PKB, p70s6k and p44/42 MAPKs, the cells were homogenized and maintained at $4{ }^{\circ} \mathrm{C}$ in $1.25 \%$ Triton containing $250 \mathrm{mM}$ sucrose, $20 \mathrm{mM}$ TrisHCl, pH 7.6, $2.5 \mathrm{mM} \mathrm{MgCl}_{2}, 50 \mathrm{mM}$ 2-mercaptoethanol, $1.2 \mathrm{mM}$ EGTA, $5 \mathrm{mM} \mathrm{Na}_{4} \mathrm{P}_{2} \mathrm{O}_{7}, 50 \mathrm{mM} \mathrm{NaF}, 1 \mathrm{mM} \mathrm{Na}_{3} \mathrm{VO}_{4}$, $30 \mathrm{U} / \mathrm{ml}$ bacitracin, $2 \mu \mathrm{M}$ leupeptin, $2 \mu \mathrm{M}$ pepstatin and $2 \mathrm{mM}$ PMSF. After centrifugation at 10,000 x g, the infranatant containing cytosol and solubilized membranes was kept at $-70^{\circ} \mathrm{C}$ until assay. An aliquot volume was taken from all membrane preparation samples for protein content determination (33).

PI3K activity was estimated as $\mathrm{PIP}_{2}$ phosphorylation to $\mathrm{PIP}_{3}$ (phosphatidylinositol bi- or tri-phosphate, respectively), in p85 immunoprecipitates obtained by treating each adipocyte membrane preparation with anti-PI3-kinase p85 and subsequent coupling to protein A agarose. The immunoprecipitates were incubated for $20 \mathrm{~min}$ at room temperature with $20 \mu \mathrm{M}\left[\gamma^{32} \mathrm{ATP}\right](5 \mu \mathrm{Ci} / \mathrm{nmol})$ in $6.25 \mathrm{mM}$ HEPES, $5 \mathrm{mM}$ $\mathrm{MgCl}_{2}$ and $0.25 \mathrm{mM}$ EGTA, and in the presence of $0.25 \mathrm{mg} /$ $\mathrm{ml}$ phosphatidylinositol/phosphatidylserine as substrate. The reaction was interrupted by the addition of $400 \mu 1$ chloroform/ methanol/HCl $(1: 2: 1, \mathrm{v} / \mathrm{v}), 150 \mu \mathrm{l}$ chloroform and $150 \mu 1$ $\mathrm{HCl}$. After centrifugation $(10,000 \mathrm{x} \mathrm{g})$, the organic phase was treated with an equal volume of methanol/100 mM $\mathrm{HCl}$ / $2.5 \mathrm{mM}$ EDTA $(1: 1: 1, \mathrm{v} / \mathrm{v})$, and the new organic phase was separated by centrifugation and then speed-vac dried. The lipidic extract, redissolved in chloroform, was spotted, together with $\mathrm{PIP}_{3}$ standard, on a silicagel TLC plate, and developed in $n$-propanol/acetic acid/ $\mathrm{H}_{2} \mathrm{O}(66: 2: 33$, v/v). Plates were dried, and radioactive $\mathrm{PIP}_{3}$ was subsequently visualized by autoradiography and analyzed by densitometric scanning. In all experiments, the densitometric measurement of the band corresponding to cells incubated in the absence of peptide, was used as the control value (20).

For the measurements of the phosphorylation degree of the respective protein kinases by immunoblotting, equal amounts of each solubilized membrane preparation sample were subjected to SDS-PAGE (34) on an $8 \%$ resolving gel in parallel with molecular weight markers. The separated proteins were then transferred to a nitrocellulose membrane in a semidry system (Trans-blot SD semidry transfer cell, Bio$\mathrm{Rad})$. For immunodetection, a Western blotting kit was used following the manufacturer's instructions, using total and phosphorylated respective antibody for each protein kinase, and a horseradish peroxidase-conjugated donkey anti-rabbit immunoglobulin second antibody, with detection by the enhanced chemiluminescence method, and quantitation by densitometric scanning of the autoradiography (20). The densitometric measurement of the phosphorylated protein kinase was normalized with respect to the total (percent of 
Table I. Effect of 10-9 M GLP-1, Ex-4, Ex-9 or insulin upon PI3K, PKB, p42/44 MAPK and p70s6k activity in adipocytes from 4-7 normal subjects and 4-6 morbidly obese patients. ${ }^{2}$

\begin{tabular}{|c|c|c|c|c|c|}
\hline & PI3K & PKB & p42 MAPK & p44 MAPK & p70s6k \\
\hline \multicolumn{6}{|c|}{ Normal subjects } \\
\hline Basal value & 100 & 100 & 100 & 100 & 100 \\
\hline GLP-1 & $155 \pm 21^{b}$ & $90 \pm 11$ & $145 \pm 17^{b}$ & $123 \pm 4^{b}$ & $110 \pm 19$ \\
\hline Ex-4 & $145 \pm 6^{\mathrm{b}}$ & $74 \pm 20$ & $158 \pm 16^{\mathrm{b}}$ & $150 \pm 7^{b}$ & $109 \pm 14$ \\
\hline Ex-9 & $173 \pm 22^{b}$ & $75 \pm 14$ & $107 \pm 13$ & $111 \pm 11$ & $109 \pm 11$ \\
\hline Insulin & $151 \pm 15^{b}$ & $231 \pm 33^{b}$ & $141 \pm 7^{b}$ & $135 \pm 18^{\mathrm{b}}$ & $94 \pm 13$ \\
\hline \multicolumn{6}{|l|}{ Obese patients } \\
\hline Basal value & 100 & 100 & 100 & 100 & 100 \\
\hline GLP-1 & $158 \pm 15^{b}$ & $99 \pm 6$ & $135 \pm 9^{b}$ & $124 \pm 7^{b}$ & $101 \pm 8$ \\
\hline Ex-4 & $144 \pm 5^{b}$ & $107 \pm 11$ & $172 \pm 10^{\mathrm{b}}$ & $157 \pm 9^{b}$ & $106 \pm 11$ \\
\hline Ex-9 & $162 \pm 18^{b}$ & $100 \pm 11$ & $154 \pm 14^{b}$ & $120 \pm 17$ & $105 \pm 7$ \\
\hline Insulin & $147 \pm 11^{b}$ & $233 \pm 11^{\mathrm{b}}$ & $131 \pm 6^{\mathrm{b}}$ & $137 \pm 9^{b}$ & $95 \pm 10$ \\
\hline
\end{tabular}

${ }^{\mathrm{a}}$ Data are means $\pm \mathrm{SEM} ;{ }^{\mathrm{b}} \mathrm{p}<0.05$ vs basal value.

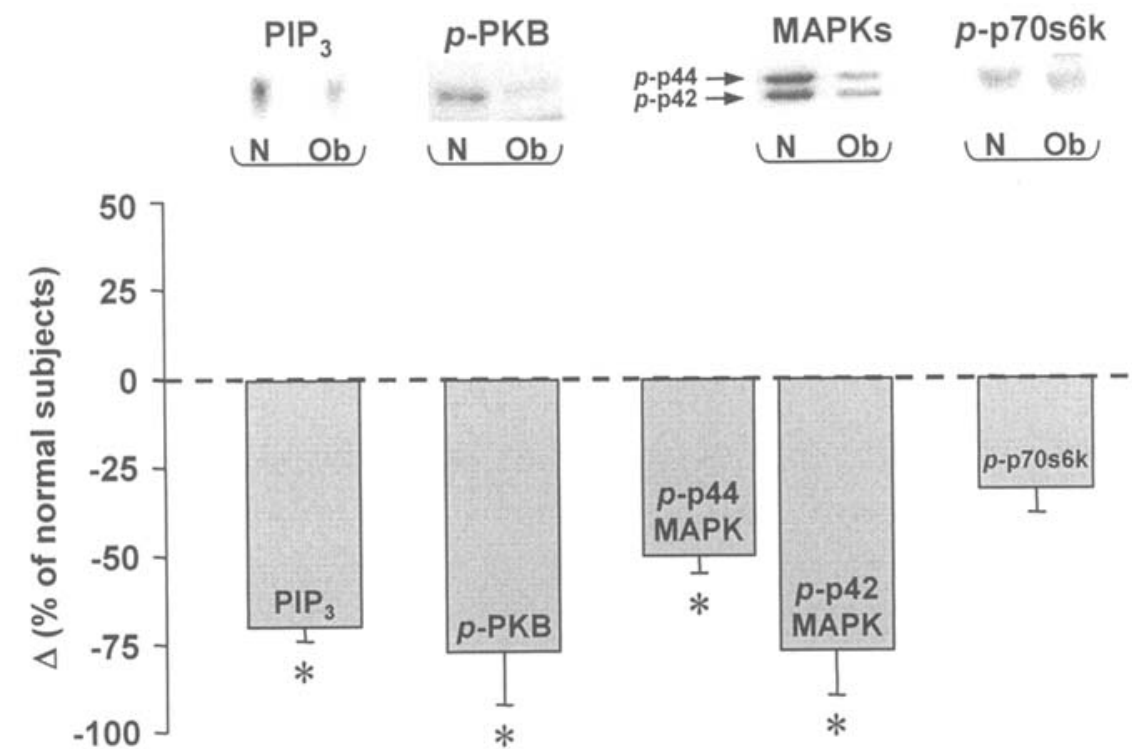

Figure 1. Basal PI3K, PKB, p44/42 MAPK and p70s6k activity in adipocytes from morbidly obese patients (Ob) compared to that in normal subjects (N). Representative immunoblot and percent increment (mean $\pm \mathrm{SEM}$ ) relative to normal subjects, ${ }^{*} \mathrm{p}<0.05$ vs normal basal value.

phosphorylated/total kinase), and the value obtained in the adipocytes incubated in the absence of peptide was used as the control value.

Glucose transport. Cells $\left(10^{5}\right)$ were incubated for $15 \mathrm{~min}$ at $37^{\circ} \mathrm{C}$ in $400 \mu \mathrm{KRB}, 10.9 \mathrm{mM}$ HEPES, $500 \mathrm{KIU} / \mathrm{ml}$ Trasylol and $2 \% \mathrm{BSA}, \mathrm{pH} 7.4$, and either without (basal) or with GLP-1, Ex-4, Ex-9 or insulin, alone or combined with $10^{-6} \mathrm{M}$ W -PI3K inhibitor- or $2.5 \times 10^{-5} \mathrm{M}$ PD -p44/42 MAPK inhibitor. This was followed by a 3 -min incubation in the additional presence of $0.2 \mu \mathrm{Ci}(6.5 \mathrm{pmol})$ of 2-deoxy-D-[1,2- $\left.{ }^{3} \mathrm{H}(\mathrm{N})\right]$ glucose (final concentration, $16.3 \mathrm{nM} 2-\mathrm{DOG}$ ). Adipocytes, after being separated at $10,900 \mathrm{x} \mathrm{g}$ in $100 \mu 1$ dioctyl phthalate, were added to a $3-\mathrm{ml}$ scintillation liquid for $\beta$-counting. The total D-glucose content was corrected for the unspecific Dglucose uptake value, obtained in cell samples from each experiment treated in parallel with $0.175 \mathrm{mM}$ cytochalasin $\mathrm{B}$ (5).

Statistical study. All data were presented as mean values ( \pm SEM) together with the number of individual determinations. The statistical significance of differences was tested using either analysis of variance or the Student's t-test.

\section{Results}

Effect on kinase activity. In adipocytes from a total of 7 normal subjects (Table I), $10^{-9} \mathrm{M}$ GLP-1, and its two 


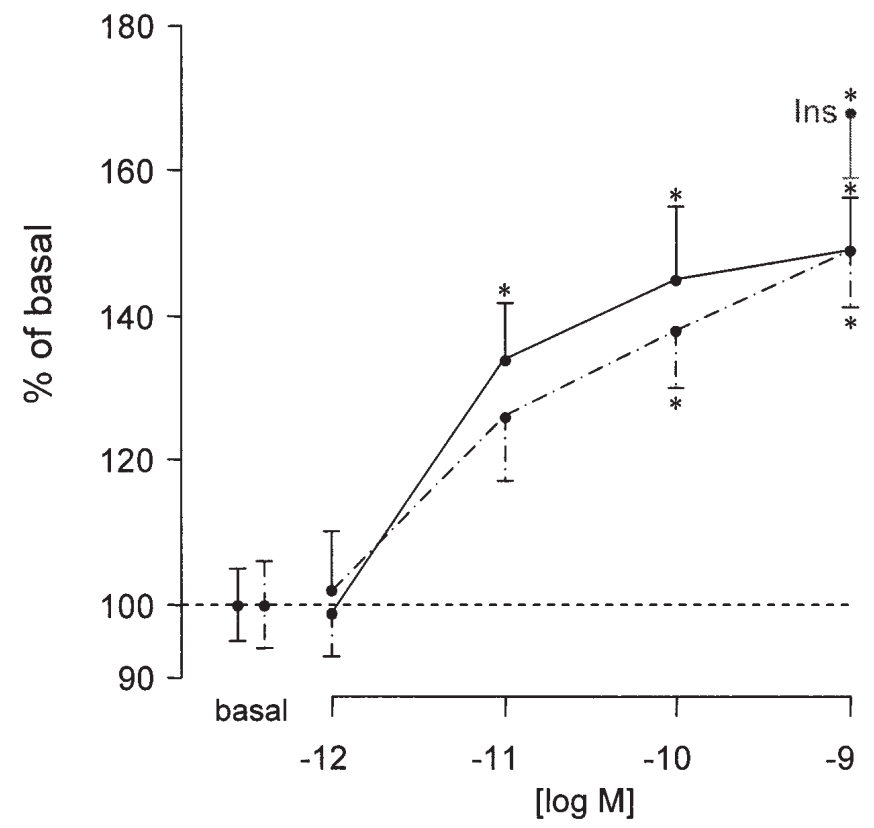

Figure 2. Effect of GLP-1 (-), Ex-4 (- -) and insulin upon 2-deoxy-Dglucose uptake in adipocytes from normal subjects. Data (mean \pm SEM) are expressed in percent of the paired basal value found within the same experiment, and refer to 11 subjects. ${ }^{*} \mathrm{p}<0.02$ vs basal value.

structurally related peptides, Ex-4 and Ex-9, all induced a clear increase $(\mathrm{p}<0.03$ or lower) in the basal PI3K activity obtained in cells incubated in the absence of the hormones/ peptides. These effects were not significantly different from one another $(\mathrm{p}<0.9)$, with an overall mean value of $157 \pm 10 \%$ of basal $(n=13)$, indistinct $(\mathrm{p}=0.752)$ from that exerted by $10^{-9} \mathrm{M}$ insulin $(\mathrm{p}<0.001)$. Except insulin, by which a clear increment in PKB phosphorylation was detected $(\mathrm{p}<0.001)$, GLP-1, Ex-4 and Ex-9 all failed to affect this enzyme. Ex-9 did not modify p42 or p44 MAP kinase activity, while both GLP-1 and Ex-4 induced a clear stimulation in p42 MAPK (overall mean value: $152 \pm 11 \%$ of basal, $n=8, p<0.01$ ), similar in magnitude $(\mathrm{p}=0.504)$ to that exerted by insulin $(\mathrm{p}<0.01)$; and the same was measured in the case of p44 MAPK (GLP-1, Ex-4 and insulin overall mean value: $134 \pm 7 \%$ of basal, $n=14$, $\mathrm{p}<0.001)$. None of the hormones/peptides tested modified the p70s6 kinase phosphorylation degree (overall mean value: $106 \pm 5 \%$ of basal, $n=21$ ).
In adipocytes from a total of 5 morbidly obese patients (Table I), the pattern of the respective incremental response of the kinases tested to each of these four hormones/peptides, was basically the same as that observed in normal adipocytes, in contrast to the response to Ex-9, by which a clear increase in p42 MAP kinase activity $(\mathrm{p}<0.001)$ was measured.

The respective basal activity of PI3K, PKB and p42/44 MAP kinases (Fig. 1) in adipocytes from these obese patients was, in all cases, reduced (overall mean value: $58 \pm 5 \%$ of normal, $\mathrm{n}=20, \mathrm{p}<0.001$ ) with respect to the corresponding value obtained in normal subjects (overall mean: 100 $\pm 7 \%$, $\mathrm{n}=21$ ), unlike that of p70s6 kinase, whose activity (obese: $84 \pm 9 \%$ of normal, $n=5$ ) showed no apparent difference $(\mathrm{p}=0.601)$ with that in normal cells $(100 \pm 12 \%, \mathrm{n}=4)$.

Uptake of 2-deoxy-D-[1,2-3 H]glucose. In adipose cells from normal subjects (Fig. 2), GLP-1 stimulated the basal glucose uptake $\left(15.3 \pm 1.7\right.$ fmol glucose $/ 10^{5}$ cells, $\left.n=37\right)$ in a doserelated manner. The increment induced was statistically significant at $10^{-11} \mathrm{M}$ up to $10^{-9} \mathrm{M}$ of the peptide, with a maximum effect from $10^{-10} \mathrm{M}$ GLP- 1 . At $10^{-9} \mathrm{M}$, the enhancing action gave a value indistinct $(\mathrm{p}=0.367)$ of that induced by the equimolar amount of insulin $(168 \pm 9 \%$ of basal, $\mathrm{p}<0.001)$. The GLP-1 structurally related peptide Ex-4 also exerted an increase in the corresponding basal glucose uptake value $\left(17.5 \pm 2.2 \mathrm{fmol}\right.$ glucose $/ 10^{5}$ cells, $\left.\mathrm{n}=30\right)$; statistically significant at $10^{-10}$ and $10^{-9} \mathrm{M}$, concentrations at which the increments induced were indistinct of those exerted by the corresponding equimolar amounts of GLP-1. Ex-9 failed to affect the glucose transport at any concentration tested; the value obtained at $10^{-9} \mathrm{M}$ representing only $114 \pm 6 \%$ of that of the basal value $\left(14.1 \pm 2.1\right.$ fmol glucose $/ 10^{5}$ cells, $\left.n=29\right)$.

The respective stimulatory action of $10^{-9}$ M GLP-1, Ex-4 or insulin $(\mathrm{p}<0.001$ in all cases) upon glucose transport in normal subjects [overall mean: $140 \pm 7 \%$ of basal $(11.5 \pm 1.3 \mathrm{fmol}$ glucose $/ 10^{5}$ cells $), n=52$ ] was completely abolished $(\mathrm{p}<0.001)$ by wortmannin (overall mean: $91 \pm 5 \%$ of basal, $n=62$ ), a PI3K inhibitor (Table II), while wortmannin alone did not apparently affect the basal value $(87 \pm 5 \%$ of basal, $n=29, p=0.092)$. The same blocking effect was detected $(\mathrm{p}<0.001)$ when PD 98059, MAP kinase inhibitory agent, was present. The overall mean value for the effect of these three hormones/peptides in the additional presence of PD 98059 represented $89 \pm 5 \%$ of

Table II. Effect of wortmannin and PD 98059, inhibitors of PI3K and MAPK respective activities, on basal and $10^{-9}$ M hormone-stimulated 2-deoxy-D-glucose uptake in adipocytes from 4-6 normal subjects. ${ }^{\mathrm{a}}$

\begin{tabular}{lrrrr}
\hline & Nil & Insulin & GLP-1 & Ex-4 \\
\hline Wortmannin & & & & $134 \pm 7^{\text {b }}$ \\
$\quad$ Nil & $100 \pm 5$ & $143 \pm 6^{\text {b }}$ & $87 \pm 10$ & $141 \pm 8^{\text {b }}$ \\
Inhibitor & $87 \pm 5$ & $100 \pm 6$ & & $84 \pm 7$ \\
PD 98059 & & & $140 \pm 8^{\text {b }}$ & $137 \pm 8^{\text {b }}$ \\
Nil & $100 \pm 9$ & $139 \pm 7^{\text {b }}$ & $85 \pm 9$ & $95 \pm 12$ \\
Inhibitor & $86 \pm 6$ & $89 \pm 9$ & & \\
\hline
\end{tabular}

${ }^{\mathrm{a}}$ Data are means $\pm \mathrm{SEM} ;{ }^{\mathrm{b}} \mathrm{p}<0.001$ vs basal value. 
the basal value $\left(14.1 \pm 2.3\right.$ fmol glucose $/ 10^{5}$ cells, $\left.n=35\right)$ compared to that in its absence (overall mean: $139 \pm 4 \%$, $\mathrm{n}=32, \mathrm{p}<0.001)$. The MAP kinase inhibitor per se did not significantly alter the basal value $(86 \pm 6 \%, n=15)$.

The stimulatory action of GLP-1 and Ex-4 upon glucose transport in normal human adipocytes differed from our previous observations (31) in cells from morbidly obese patients, in which no effect of either of these two peptides could be detected, while cells maintained their normal response to insulin, accompanied also by a normal basal value.

\section{Discussion}

We have previously provided information on the role of GLP-1 in the control of glucotransporter expression, glucose and lipid metabolism in human and/or rat liver, muscle and fat tissue (2), and on the characteristics of its effects on the diabetic state $(2,5,35)$. In recent studies of morbidly obese patients, we have also documented the possible participation of GLP-1 in the normalization of their metabolic conditions after bariatric surgery (24), and its action and that of exendins upon glucose transport and lipid metabolism of adipocytes (31).

The present study has explored the effect of GLP-1 and exendins upon the activity of kinases (known to be actively involved in other extrapancreatic tissues) $(20,21,29)$ in the adipose tissue of morbidly obese patients, compared to normal subjects. All of the hormones/peptides tested (GLP-1, Ex-4, Ex-9 and insulin) induced a clear and similar increase in the PI3K activity in adipocytes from the obese group, equivalent in magnitude to that exerted in normal cells. No modification in PKB, though, was observed in any of the two groups with GLP-1 or either exendin, while the obese cells maintained their normal response capability to insulin. No effect on p70s6k was measured under any condition, indicating the absolute lack of participation of this enzyme. Our data also revealed that both GLP-1 and Ex-4 stimulated, like insulin, p42 and p44 MAP kinase activity in normal and obese cells. However, Ex-9, by which no effect could be detected in normal adipocytes, induced a clear increment in the p42 MAPK activity in the obese patients.

Despite the fact that the incremental responses of PI3K, PKB and MAPKs to GLP-1, Ex-4 and insulin in the obese cells were, as a rule, the same as those in normal adipocytes, this was not the case regarding the corresponding basal level of each enzyme which, in fact, proved to be significantly reduced. Apart from further considerations, the latter suggests that the net corresponding activity reached after stimulation with GLP-1, Ex-4 or insulin in the obese group was, in all cases, much lower than that in normal subjects. An alteration in cellular enzyme activity has been previously reported in other disorders associated with impaired glucose metabolism. Relative to this, a higher basal PI3K activity in muscle tissue or cells was detected in type 2 diabetic patients $(35,36)$, accompanied by both a lower than normal glucose transport and glycogen synthase $\alpha$ activity and a higher glycogen synthesis (35). In fact, in obese patients (31), no significant effect of GLP-1 upon glucose transport, and a reduction of the adipocyte basal value by both exendins, were reported, while in the fat cells of the present group of normal subjects, GLP-1 and Ex-4 stimulated the uptake of glucose to the same level as that reached by equimolar concentrations of insulin. In the normal group, no modification of the basal value by Ex-9 was measured, in contrast to its observed GLP-1-like effects upon parameters of the glucose or lipid metabolism in other human extrapancreatic tissues $(8,29,31)$, or to its GLP-1-agonistic character in adipocyte (30) and myocyte (12) cell lines. Nevertheless, the present results do not allow us to conclude whether GLP-1 and Ex-4 exert their effects through the same or a different signalling pathway, but indicate a relevant role of PI3K and MAPKs in their action upstream in glucose metabolism. In fact, the GLP-1or Ex-4-induced increase in glucose uptake in normal adipocytes was highly reduced by respective inhibitors of these cellular enzymes.

The present results on $\mathrm{PKB}$, which is stimulated by insulin but not by GLP-1 or either exendin in human adipocytes, were also observed in normal rats (5), whereas this negative effect was reversed. However, in the adipose cells of a STZ-induced type 2 diabetic rat model, where there was also evidence of other anomalies such as an increased basal PI3K activity. However, apart from possible species differences in hormonal action, the obese patients in this study, as far as we are aware, did not present a defect in insulin secretion or action. As a matter of fact, a section of the total participating population of obese patients here, all having the same characteristics, GLUT-4 expression, protein and mRNA, showed only a slight trend toward lower values as compared to normal subjects (31), contrary to other reports (37-39) in which patients suffering obesity associated with insulin resistance or type 2 diabetes presented significantly reduced adipocyte glucotransporter expression.

The increasing effect of Ex-9 upon p42 MAPK activity, solely detected in the obese group, associated with no modification of the adipocyte glucose uptake basal value as it occurs in normal conditions, indicates a possible correlation of this enzyme with an action of the peptide in fat tissue other than that upon glucose transport, such as that reported upon lipogenesis in morbidly obese patients (31).

To conclude, GLP-1 and Ex-4, like insulin, but not Ex-9, increase glucose transport in normal human adipocytes, and this effect is mediated by an activation of protein kinases. The fact that this stimulatory action does not seem to be maintained in morbidly obese subjects, suggests that the proposed participation of GLP-1 in the normalization of the metabolic conditions of these patients may occur through its effects upon the lipid metabolism; but perhaps also through its known action upon glucose transport and/or metabolism in other extrapancreatic tissues such as liver and muscle, which in human obesity remains to be investigated.

\section{Acknowledgements}

We are grateful to E. Martín-Crespo for the excellent technical work. This study was supported by a grant from the Institute of Health Carlos III (PI 060076 and RD06/ 0015/0004), Spain. V.S., B.N., L.A. and N.G. are Research Fellows from the Fundación Conchita Rábago de Jiménez Díaz. The authors declare that there is no conflict of interest that would prejudice the impartiality of the reported research. 


\section{References}

1. Creutzfeldt W: The entero-insular axis in type 2 diabetes. Incretins as therapeutic agents. Exp Clin Endocrinol Diabetes 109: S288-S303, 2001

2. Valverde I, Villanueva-Peñacarrillo ML and Malaisse WJ: Pancreatic and extrapancreatic effects of GLP-1. Diabetes Metab 28: S385-S389, 2002.

3. Villanueva-Peñacarrillo ML, Puente J, Redondo A, Clemente F and Valverde I: Effect of GLP-1 treatment on GLUT2 and GLUT4 expression in NIDDM and IDDM rats. Endocrine 15: 241-248, 2001

4. Acitores A, González N, Sancho V, Arnés L, Valverde I, Malaisse WJ and Villanueva-Peñacarrillo ML: Participation of protein kinases in the stimulant action of GLP-1 upon 2-deoxyD-glucose uptake by normal rat skeletal muscle. Horm Metab Res 37: 275-280, 2005

5. Sancho V, Trigo MV, González N, Valverde I, Malaisse WJ and Villanueva-Peñacarrillo ML: Effects of GLP-1 and exendins on kinase activity, 2-deoxy-D-glucose transport, lipolysis and lipogenesis in adipocytes from normal and streptozotocininduced type 2 diabetic rats. J Mol Endocrinol 35: 27-38, 2005.

6. Valverde I, Morales M, Clemente F, López-Delgado MI, Delgado E, Perea A and Villanueva-Peñacarrillo ML: Glucagon-like peptide-1: a potent glycogenic hormone. FEBS Lett 349: 313-316, 1994.

7. Villanueva-Peñacarrillo ML, Alcántara A, Clemente F, Delgado E and Valverde I: Potent glycogenic effect of GLP-1(7-36)amide in rat skeletal muscle. Diabetologia 37: 1163-1166, 1994.

8. Luque MA, González N, Márquez L, Acitores A, Redondo A, Morales M, Valverde I and Villanueva-Peñacarrillo ML: GLP-1 and glucose metabolism in human myocytes. J Endocrinol 173: 465-473, 2002.

9. Valverde I, Mérida E, Delgado E, Trapote MA and Villanueva-Peñacarrillo ML: Presence and characterization of glucagon-like peptide-1(7-36)amide receptors in solubilized membranes of rat adipose tissue. Endocrinology 132: 75-79, 1993.

10. Villanueva-Peñacarrillo ML, Delgado E, Trapote MA Alcántara AI, Clemente F, Luque MA, Perea A and Valverde I: Glucagon-like peptide-1 binding to rat hepatic membranes. J Endocrinol 146: 183-189, 1995.

11. Delgado E, Luque MA, Alcántara A, Trapote MA, Clemente F, Galera C, Valverde I and Villanueva-Peñacarrillo ML: Glucagon-like peptide-1 binding to rat skeletal muscle. Peptides 16: 225-229, 1995.

12. Yang H, Egan JM, Wang Y, Moyes D, Roth J, Montrose MH and Montrose-Rafizadeh C: GLP-1 action in L6 myotubes is via a receptor different from the pancreatic GLP-1 receptor. Am J Physiol 275: C675-C683, 1998.

13. Thorens B: Expression cloning of the pancreatic beta cell receptor for the gluco-incretin hormone glucagon-like peptide-1. Proc Natl Acad Sci USA 89: 8641-8645, 1992.

14. Ruiz-Grande C, Alarcón C, Mérida E and Valverde I: Lipolytic action of glucagon-like peptides in isolated rat adipocytes. Peptides 13: 13-16, 1992.

15. Perea A, Viñambres C, Clemente F, Villanueva-Peñacarrillo ML and Valverde I: GLP-1(7-36)amide effects on glucose transport and metabolism in rat adipose tissue. Horm Metab Res 9: 417-421, 1997.

16. Villanueva-Peñacarrillo ML, Márquez L, González N, Díaz-Miguel M and Valverde I: Effect of GLP-1 on lipid metabolism in human adipocytes. Horm Metab Res 33: 73-77, 2001.

17. Márquez L, Trapote MA, Luque MA, Valverde I and Villanueva-Peñacarrillo ML: Inositolphosphoglycans possibly mediate the effects of glucagon-like peptide-1(7-36)amide on rat liver and adipose tissue. Cell Biochem Funct 16: 51-56, 1998.

18. Galera C, Clemente F, Alcántara A, Trapote MA, Perea A, López-Delgado MI, Villanueva-Peñacarrillo ML and Valverde I: Inositolphosphoglycans and diacylglycerol are possible mediators in the GLP-1(7-36)amide glycogenic effect in BC3H-1 myocytes. Cell Biochem Funct 14: 43-48, 1996.

19. Trapote MA, Clemente F, Galera C, Morales M, Alcántara AI, López-Delgado MI, Villanueva-Peñacarrillo ML and Valverde I: Inosytolphosphoglycans are possible mediators of the glucagonlike peptide-1(7-36)amide action in the liver. J Endocrinol Invest 19: 114-118, 1996.

20. Redondo A, Trigo V, Acitores A, Valverde I and Villanueva-Peñacarrillo ML: Cell signalling of the GLP-1 action in rat liver. Mol Cell Endocrinol 204: 43-50, 2003.
21. Acitores A, González N, Sancho V, Valverde I and Villanueva-Peñacarrillo ML: Cell signalling of the glucagonlike peptide-1 action in rat skeletal muscle. J Endocrinol 180: 389-398, 2004.

22. Ranganath LR, Beety JM, Morgan LM, Wright JW, Howland R and Marks V: Attenuated GLP-1 secretion in obesity: cause or consequence? Gut 38: 916-919, 1996.

23. Lugari R, Dei Cas A, Ugolotti D, Barilli AL, Camellini C, Ganzerla GC, Luciani A, Salerni B, Mittenperger F, Nodari S, Gnudi A and Zandomeneghi R: Glucagon-like peptide 1 (GLP1) secretion and plasma dipeptidyl peptidase IV (DPP-IV) activity in morbidly obese patients undergoing biliopancreatic diversion. Horm Metab Res 36: 111-115, 2004.

24. Valverde I, Puente J, Martín-Duce A, Molina L, Lozano O, Sancho V, Malaisse WJ and Villanueva-Peñacarrillo ML: Changes in glucagon-like peptide-1 (GLP-1) secretion after biliopancreatic diversion or vertical banded gastroplasty in obese subjects. Obes Surg 15: 387-397, 2005.

25. Cancelas J, Villanueva-Peñacarrillo ML, Valverde I and Malaisse WJ: Synergistic insulinotropic effects of succinic acid dimethyl ester and exendin-4 in anaesthetized rats. Int J Mol Med 8: 269-271, 2001.

26. Alcántara AI, Morales M, Delgado E, López-Delgado MI, Clemente F, Luque MA, Malaisse WJ, Valverde I and Villanueva-Peñacarrillo ML: Exendin-4 agonist and exendin(939)amide antagonist of the GLP-1(7-36)amide effects in liver and muscle. Arch Biochem Biophys 341: 1-7, 1997.

27. Nielsen LL, Young AA and Parkes DG: Pharmacology of exenatide (synthetic exedin-4): a potential therapeutic for improved glycemic control of type 2 diabetes. Regul Peptides 117: 77-88, 2004.

28. Cancelas J, Villanueva-Peñacarrillo ML, Valverde I and Malaisse WJ: Suppression by exendin(9-39)amide of glucagonlike peptide 1 insulinotropic action in rats infused with the dimethyl ester of succinic acid. Endocrine 15: 283-285, 2001.

29. González N, Acitores A, Sancho V, Valverde I and Villanueva-Peñacarrillo ML: Effect of GLP-1 on glucose transport and its cell signaling in human myocytes. Regul Peptides 126: 203-211, 2005.

30. Montrose-Rafizadeh C, Yang H, Wang Y, Roth J, Montrose MH and Adams LG: Novel signal transduction and peptide specificity of glucagon-like peptide receptor in 3T3-L1 adipocytes. J Cell Physiol 172: 275-283, 1997.

31. Sancho V, Trigo ML, Martín-Duce A, González N, Acitores A, Arnés L, Valverde I, Malaisse WJ and Villanueva-Peñacarrillo ML: Effect of GLP-1 on D-glucose transport, lipolysis and lipogenesis, in adipocytes of obese subjects. Int J Mol Med 17 : 1133-1137, 2006

32. Rodbell M: Metabolism of isolated fat cells. I. Effects of hormones on glucose metabolism and lipolysis. J Biol Chem 239: 375-380, 1964

33. Bradford MM: A rapid and sensitive method for the quantitation of microgram quantities of protein utilizing the principle of protein dye binding. Anal Biochem 72: 248-254, 1976.

34. Laemli UK: Cleavage of structural proteins during the assembly of the head of bacteriophage T4. Nature 227: 680-685, 1970

35. González N, Sancho V, Martín-Duce A, Tornero-Esteban P, Valverde I, Malaisse WJ and Villanueva-Peñacarrillo ML: GLP-1 signalling and effects on glucose metabolism in myocytes from type 2 diabetic patients. Int J Mol Med 16: 747-752, 2005.

36. Meyer MM, Levin K, Grimmsmann T, Beck-Nielsen H and Klein HH: Insulin signalling in skeletal muscle of subjects with or without type II-diabetes and first degree relatives of patients with the disease. Diabetologia 45: 813-822, 2002.

37. Garvey WT, Malanu L, Huecksteadt TP, Bimbaum MJ, Molina JN and Ciaraldi TP: Pretranslational suppression of a glucose transporter protein causes insulin resistance in adipocytes from patients with non-insulin-dependent diabetes mellitus and obesity. J Clin Invest 87: 1072-1081, 1991.

38. Sinha MK, Rainieri-Maldonado C, Buchanan C, Pories WJ, Carter-Su C, Pilch PF and Caro JF: Adipose tissue glucose transporters in NIDDM. Decreased levels of muscle/fat isoform. Diabetes 40: 472-477, 1991.

39. Giacchetti G, Faloia E, Taccaliti A, Morosini PP, Arnaldi G, Soletti F, Mantero F, Accili D and De Pirro R: Decreased expression of insulin-sensitive glucose transporter mRNA (GLUT-4) in adipose tissue of non-insulin-dependent diabetic and obese patients: Evaluation by a simplified quantitative PCR assay. J Endocrinol Invest 17: 709-715, 1994. 